\title{
SPATIAL ORIENTATION AND GRAMMATICALIZATION
}

\author{
KATALIN SIPŐCZ
}

\begin{abstract}
The focus of this paper is on a probably universal type of grammaticalization whereby body part terms turn into place-denoting morphemes (adverbs, postpositions or local case markers). The linguistic expressions of the major areas of deictic orientation in the Mansi language are analysed on the basis of their lexical sources. According to general typological studies, the lexical origin of spatial morphemes shows considerable agreement across languages of the world: most of them go back to names of body parts. The paper shows that body part term sources follow the universal patterns in Mansi, too: in that language, 'back', 'head', and 'heart' have turned into general spatial markers. Exploring the system of spatial morphemes in Mansi, the paper argues that the etymology of those morphemes often reveals what is called a "relational objectpart" origin; that class of sources is frequently attested in the typological literature, too. Finally, the paper tries to find out how unequivocally the body part terms that have turned into spatial markers can be determined. It is concluded that data from the various Uralic languages contradict some of the general statements found in the typological literature.
\end{abstract}

\section{Introduction}

This paper will be concerned with one of the most general and presumably universal types of grammaticalization: that of names of body parts. The grammaticalization of names of body parts may take several directions: they may turn into pronouns (primarily reflexive, emphatic, or reciprocal ones), or numerals; the noun meaning 'hand' often develops into a possessive marker (cf. lay one's hands on sg > (begin to) possess sg), the noun meaning 'head' occurs in a variety of abstract grammatical roles (cf. the head as the centre of intellectual activity). Names of body parts may also develop into various other types of suffixes (e.g., English -ly< ${ }^{*}$ liç 'body': manly $<{ }^{*}$ mann-liç). ${ }^{1}$ The most general direction of their grammaticalization, however, results in place-denoting expressions: adverbs, adpositions, or suffixes (Heine et al. 1991, 152; Heine 1997, 19-29, 35-66; Heine 1999; Svorou 1993, 70-77).

${ }^{1}$ Cf. Bybee: http://www.unm.edu/ jbybee/Cognitive.doc 
The linguistic partitioning of space, i.e., the linguistic projection of spatial orientation is a topic that has for a long time occupied the attention of not only linguists but also researchers in other disciplines more or less related to linguistics, simply because the relationship between spatial cognition and language raises a number of diverse issues. Due to an upswing of cognitive linguistic research, a number of projects have targeted this area in the past few decades and numerous papers have given new perspectives to these issues. As a consequence of the basic character of cognitive research, such investigations are often concerned with to what extent and in what ways spatial systems found in the individual languages are universal or language particular.

\section{Egocentric and anthropomorphic features of spatial orientation}

It is a matter of common knowledge that languages are fundamentally anthropocentric; one of the most telling examples of this is that most spatial terms are anthropomorphic. In determining the various directions, positions, and places, our own body and its parts constitute a natural (central) point of departure. The semantics of body parts is relational in the first place as the meanings of these terms involve part/whole relationships and - consequently - positional components. Due to the anthropomorphic and egocentric nature of language, what is behind us is at the back, what is to the right or to the left is sideways, what is in front of us is facing us, etc. The body part origin of the most general locative expressions is widespread in any language.

That "body-centred" character is present in other features of spatial language as well. Our perception of space is organized along three axes: the vertical axis is based on our experience of gravitation but the horizontal axis producing the opposition FRONT-BACK ${ }^{2}$ as well as the lateral axis telling right from left are based on the human body. If we want to refer to the position of inanimate objects, we have to localize them in the given space and we have to determine their parts (front, back, etc.), an activity in which an anthropocentric starting-point is essential. A factor that plays a role in that process is similarity of shape, the analogy of the human body, whenever a body-like perception of the given object is

2 Terms like FRONT, BACK, IN, OUT, UP, DOWN, etc. are symbols of basic spatial categories. 
possible. In fact, this is what accounts for the widespread polysemy of body part terms observable in all languages, e.g., the leg of a table, the eye of a needle, the neck of a bottle, the toe and tongue of a shoe, the back of a chair, the spine of a book, the rib and the foot of a hill, etc. Such anthropomorphic and egocentric character is also observable where there is no similarity whatsoever between the given object and the human body (or the body of an animal). We can furthermore observe that the orientation of objects may also be influenced by their functions. The front of a cupboard is at its door, that of a TV set is at its screen, and that of a telephone is on the side where you can dial. That is, the front of an object is the part at which human activity is directed in the case of the given object. This is explained partly by egocentrism, and partly by anthropomorphism, since it is obvious with respect to a human body, too, which side is the dominant one (we face forward, we communicate forward, the activity of our hands is also directed to the front). In the case of moving objects, the direction of motion determines their orientation. The part of an object that is in the direction of its motion is perceived as its front; again, the similarity with the human body is straightforward. ${ }^{3}$ Also, the concepts of IN and OUT, just like the category of BOUNDARY in general, are based on the analogy of the boundaries of, and the cavities within, the human body.

Anthropocentricity is also revealed by the existence of local expressions that are applied to people only. This property is exhibited, e.g., by Finnish adverbs of the kasvokkain ( $<$ kasvo 'face'), nenäkkäin (< nenä 'nose'), nokikkain (< nokka 'beak') 'opposite' type whose use generally implies a human participant (Ojutkangas 2001, 66). The Hungarian postposition/adverb szemben 'opposite' (< szem 'eye') is historically similar: its early uses were in the sense 'in somebody's field of sight' (Benkö 1967-1976, III.712). Interestingly, such anthropocentrism also characterizes local expressions that are not of a body part origin. For instance, Svorou writes with respect to the earliest attested prepositional uses of before, behind that they initially occurred with pronouns referring to people (Svorou 1993, 119). All of that is naturally connected to the basically anthropocentric nature of spatial perception.

\footnotetext{
${ }^{3}$ According to Jackendoff and Landau, such orientation of objects is determined by their natural axes: the nature of the main axes (horizontal vs. vertical, directed vs. undirected, etc.) determines what is referred to as the beginning or end of a given object, its top or bottom, etc. (Jackendoff-Landau 1992, 99-123).
} 
Spatial terms of a body part origin may be based on both human and animal bodies; that is, they may be both anthropomorphic and zoomorphic in character. But even the latter are anthropocentric: in the perception of the body of an animal, too, human perspective prevails: animals' bodies are usually perceived in terms of species that are important for people, i.e., domestic animals or game. ${ }^{4}$ In languages where the lexical source of the reference area UP is a body part term referring to the back of an animal, the semantic change may have been fostered by the fact that people mount (sit on top of) saddle animals.

\section{Universal features of grammaticalization of the type body part $>$ spatial morpheme ${ }^{5}$}

In what follows, spatial terms that originate in body part names will be investigated.

Typological studies of such semantic changes of body part terms have been conducted by Svorou (1993, 70-109), as well as Heine and his coworkers (cf. Heine 1997, 35-65). Svorou's studies are based on data from languages belonging to a variety of language families (he collected spatial terms going back to names of body parts from 55 languages); Heine primarily built his own investigations on data coming from languages of Africa and Oceania. In what follows, I will briefly review claims of the studies mentioned that may serve as an important basis of comparison from the point of view of the present paper. Although the methods of these two authors were slightly different, the nature of my own investigations makes it possible to "add up" their claims and discuss probably universal lexical sources of spatial morphemes in an integrated fashion. (This is not difficult to do partly because the linguistic data - the source lexemes - themselves are largely identical.)

With respect to the lexical sources of place-denoting morphemes, Svorou says that nominal sources are the most frequent but, less often, verbs and sporadically other part-of-speech categories (adverbs, adjectives, participles, and even conjunctions and numerals) are attested in

\footnotetext{
${ }^{4}$ Heine (1989) calls this the 'pastoralist' model, pointing out that such names are mainly characteristic of East-African pastoral communities. Given that this type also occurs elsewhere, the term 'zoomorphic' seems to be more appropriate (Svorou 1993, 73).

${ }^{5}$ Svorou - following Bybee - uses the term 'spatial gram' (op.cit., 216).
} 
that role. She classifies nominal sources into four groups (op.cit., 66-9), of which the most general group involves (1) names of body parts proper, followed by (2) the "relational object-part class" (side, middle, back, front, etc., cf. Hungarian elöl 'in front', alul 'at bottom'), (3) the "environmental landmark class" (sky, land, field, road, trace, house, etc., cf. Hungarian után 'after' < út 'road'), and (4) the "abstract spatial notion class" (place, length, direction, etc., cf. Hungarian között 'between' < köz 'interstice, interval'). Heine divides nominal sources into (1) body part names and (2) landmark terms. With respect to relational part names, forming a distinct group in Svorou's classification, he points out that these come from either body part names or general spatial terms; hence, etymologically, they can be seen as belonging one or the other group.

On the basis of the data it can be concluded that local expressions going back to body part terms are usually static in character but counterexamples also occur: in some languages it can be observed that the word meaning 'eye' has turned into an allative marker 'toward, in the direction of' or that the word for 'hand' has grammaticalized into an ablative marker (Svorou 1993, 78).

Let us now survey the ways in which the main areas of deictic orientation, ${ }^{6}$ the regions of UP, DOWN, FRONT, BACK, BESIDE and $\mathrm{IN}^{7}$ have been given names by the languages these two authors investigated.

UP: The name of the notion UP is based on a body part in most languages, and in particular on the word for 'head'. Further body part terms that serve as sources of local expressions belonging here are 'face', 'shoulder', 'hair', 'forehead', and 'back'.

With respect to 'back', we have to mention that the spatial expressions of languages may not only follow the anthropomorphic model but also the

${ }^{6}$ Spatial orientation can be subdivided into absolute (cardinal) and relative (de-
ictic) orientation. For the former, the position of the observer is irrelevant (e.g.,
orientation in terms of cardinal directions), whereas in the relative framework,
orientation is always with respect to something. The base of comparison is usu-
ally the speaker. Spatial grammatical morphemes based on body part terms,
understandably, mostly belong to the realm of deictic orientation.
7 The main reference areas differ between Heine's and Svorou's studies: Heine fails
to mention the region BESIDE, whereas Svorou further adds BETWEEN, AT THE
EDGE OF, TOWARD, THROUGH, etc. The six categories investigated in the present
paper are the most general relative areas based on a canonical view of the human
body. 
zoomorphic one (cf. section 2). On the basis of an animal body, 'back' is UP, 'head' is in FRONT, and 'tail' or 'rump' is at the BACK. The investigations have not revealed a single language whose spatial expressions are exclusively based on the zoomorphic model, the anthropomorphic model being more general in all cases. Zoomorphic terms are secondary also in the sense that while they presuppose the existence of anthropomorphic ones, the converse does not hold. Spatial terms of the zoomorphic kind typically evolve from body part names that are only used for animal bodies (like 'tail') ${ }^{8}$ (Svorou 1993, 75).

DOWN: According to Heine, it is only in the case of the DOWN area that body parts are in a minority as conceptual sources. In this area, the sources are mainly connected to what is called the landmark model, characteristically having a basic meaning like 'land' or 'earth'. In terms of Svorou's data, on the other hand, this area also follows the body part pattern in the first place. Sources of a body part origin include 'bottom', 'rump', 'foot', and 'hip'.

FRONT: For this meaning, it is basically 'face' and 'eye' that are attested, but 'breast', 'forehead', 'mouth', 'head', and 'belly' also occur as sources.

BACK: Here the use of the body part term 'back' is practically universal (in the languages of Oceania, it represents 95\%), butpresumably using the zoomorphic pattern - 'bottom', 'rump', 'groin', and 'anus' also occur.

BESIDE: The body part sources of the spatial morphemes belonging here are 'side', 'rib', 'belly', 'heart', and 'ear'.

IN: The body part names meaning 'belly', 'palm', 'tooth', 'heart', 'liver', 'bowels', 'mouth', 'neck', and 'blood' serve as conceptual sources here.

\footnotetext{
${ }^{8}$ On the basis of the foregoing, it can be stated that the HUMAN - ANIMAL distinction among body part terms may be implemented in three different ways: (1) "parallel" body parts have different names (e.g., Hungarian kéz 'hand' vs. mancs 'paw', arc 'face' vs. pofa 'muzzle'; (2) a body part name only applies to people or only to animals (e.g., Hungarian váll 'shoulder', hónalj 'armpit' vs. farok 'tail', szarv 'horn'); (3) the grammaticalization of the same body part term results in different concepts (e.g., 'back' > BACK vs. UP).
} 
In the Appendix, the entries of World Lexicon of Grammaticalization (Heine-Kuteva 2002) that show grammaticalization of body part terms are listed, as well as the ones discussing the lexical sources of the main spatial positions. The above are in agreement with what is included in that lexicon although the latter includes some novel elements, too.

\section{Spatial morphemes based on body part terms in Mansi}

In what follows, the results of typological studies will be compared to the data of the Mansi language.

In Mansi, the body part terms listed here have developed into adverbs

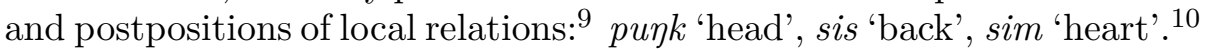

$\mathrm{N} p u \eta k \sim p o \eta k, \mathrm{LM} \mathrm{LU} p \emptyset \eta k \sim p \ddot{a} \eta k, \mathrm{P} p \emptyset \eta k, \mathrm{~K} p \ddot{a} \eta k, \mathrm{~T} p \emptyset \eta$ 'head' serve to refer to the concept UP, and with case suffixes added they can also signal the usual "three-directional" pattern ('to'/'at'/'from'). Their postpositional use for denoting local relations is attested primarily in folklore texts, it is not characteristic of newer Mansi texts. Cf.:

(1) (a) LM wånkhä pänknè 'to above the pit' [pit-head-lat.]

(Munkácsi-Kálmán 1986, 481)

(b) T $\underline{v ø \eta \emptyset l-p \emptyset \eta t}$ tōjt pätím ål 'on top of the log there is snow' [log-head-loc.]

(Munkácsi 1892-1921, IV.402)

(c) T tārèm-pøฤnèl 'from the sky' [sky-head-abl.]

(Munkácsi 1892-1921, IV.401)

The body part name that has grammaticalized to the largest extent and is

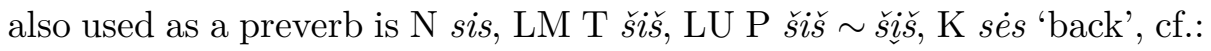

(2) (a) LU kwäl šišne minèn! 'Go behind the house!' [house-back-lat.]

(Munkácsi-Kálmán 1986, 552)

(b) $\mathrm{N}$ ańt-ńālèm sisin kwol sisèmnèl ti vislem 'I have produced my arrow made of horn from behind my house' [house-back-PxSg1-abl.]

(Munkácsi 1892-1921, II.178)

${ }^{9}$ Mansi case suffixes do not include any with a demonstrably body part origin. Adverbs and postpositions going back to body part names invariably contain a local case marker; telling them apart from "simple" case-marked nominals may be problematic in some cases, cf. section 8 .

${ }^{10}$ Abbreviations: $\mathrm{N}=$ Northern dialect, $\mathrm{LM}=$ Middle-Lozva dialect, $\mathrm{LU}=$ LowerLozva dialect, $\mathrm{P}=$ Pelym dialect, $\mathrm{K}=$ Kondinsky dialect, $\mathrm{T}=$ Tavda dialect, $\mathrm{PU}=$ Proto-Uralic, PFU = Proto-Finno-Ugric. 


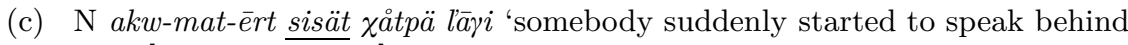
him' [back-PxSg3-loc.]

The word occurs as a local expression both in folklore texts and in more recent field notes; it is one of the most general signals of the reference area BACK along with juji-pālt. Similarly to other place adverbials, it

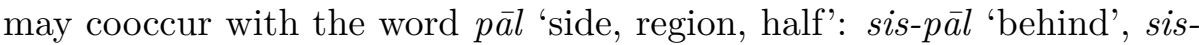

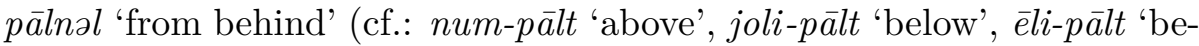
fore', etc.), and it can also occur as a preverb: сысы минантанкве 'уезжать', сысы минункве 'уехать, уйти', сысы тотызлалункве 'уносить' (Rombandeeva-Kuzakova 1982, 115). In its role as a preverb, abandoning its original local meaning, it may also fulfil a perfectivising function.

The body part term to signal the area IN is N sim, LM LU P šim, $\mathrm{K}$ sèm, T šåm $\sim \check{g} \varnothing m$, meaning 'heart, inner part, central part' (in some dialects, also 'stomach'). Cf.:

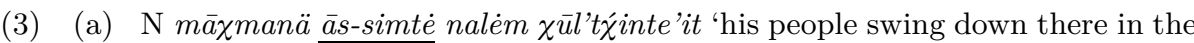
middle of the river Ob' [Ob-heart-loc.] (Munkácsi 1892-1921, II.213)

(b) N luwè kārtä simänèl 'from the middle of his yard with horses' [yard-PxSg3heart-PxSg3-abl.]

(Munkácsi 1892-1921, II.325)

The locative use of sim mainly occurs in folklore texts; in colloquial Mansi, a more general term for this area, also of a nominal origin, is the postposition kiwer ( < 'internal part, the inside of sg').

Comparing the Mansi data with the typological claims reviewed above, we can see that, with respect to the range of body part terms used as conceptual sources, Mansi does not depart from the patterns that are usual in other languages: 'head' and 'back' are the most widespread there, too, for UP and BACK; 'heart' also occurs in other languages as a possible name for IN.

\section{The origin of spatial morphemes in Mansi}

In order to get the full picture of the spatial system of Mansi (remaining in the framework studied so far), let us review the most general or primary terms (i.e., the most frequent ones, occurring outside folklore texts, exhibiting the three-directional system, and occurring both as adverbs and as postpositions) for the six spatial positions. In the list, only 
northern dialects are included with their etymologies as in the Uralisches Etymologisches Wörterbuch:

(4) UP: num- $<{ }^{*} n u-m 3$ 'das Obere, Himmel; Gott' PU

(Rédei 1986-1988, 308)

DOwn: jol- $<*$ ala 'Raum, unter etw., Unter-, das Untere-' PU

FRONT: $\bar{e} l-<* e \delta e$ 'das Vordere, Raum vor etw., Vorder' PFU

BACK: sis- $<*$ *cänčä 'Rücken' PFU

(ibid., 56)

juji (ju-) 'back part, at back (inside)' $<$ ?

BESIDE: $p \bar{o} \chi$ - 'side, at the side' $<$ ?

IN: kiwar $<*$ kirk3 'Inneres, Höhlung' PFU

(ibid., 161)

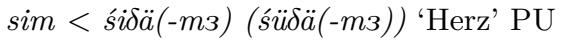

(ibid., 477)

(cf. also: $j u j i, j u-$ )

The stems serving to refer to the six basic areas of deictic orientation in Mansi are drastically shortened function words of an ancient origin, and the conceptual sources cannot as a rule be captured in the synchronic system of the language. The etymology of these words reveals, in many cases, a rather general basic meaning of the type 'the front, lower part, inside, etc. of something'. Exceptions are the body part origins of sis for BACK $(<$ 'back') and sim for IN ( $<$ 'heart'). On the basis of the ancient meanings assumed for UP, we could perhaps suspect the presence of the landmark model. For the rest of the areas, the conceptual sources belong to the second most frequent category of Svorou's system, relational parts of objects. The connection between relational concepts and spatial morphemes can be spotted not only by historical analysis but also within the synchronic system, cf. kiwar 'the inside of sg' : kiwarn 'into'-kiwart

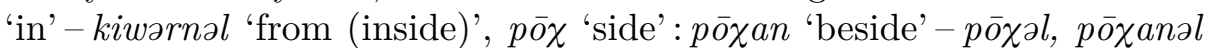
'from beside, from the side of', os 'surface, face': T åšən 'onto'-åšnal 'off' - åšt 'on (top of)'.

Svorou (1993, 84-5) claims that these nouns also used to be body part terms (or names of spatial positions), and their turning into relational part names in fact represents the first step of their grammaticalization. This assumption is definitely supported by the general tendency of semantic change concrete $>$ abstract, as well as the fact that, in a number of languages, lexemes of this type are often polysemous with some body part term, cf. Mansi $p \bar{o} \chi$ 'side in general; side of the (human) body', os 'surface; face'. Heine (1997, 39-40) claims that such relational terms simply cannot be told apart from spatial terms; their differences are morphosyntactic at best. Whereas the latter belong to the group of adverbs 
or adpositions, the former are nouns. They cannot be seen as prototypical nouns, however; they often lack features like number or definiteness.

\section{Proto-Uralic antecedents}

A hypothetical proto-language system exhibits similar phenomena: ${ }^{11}$ the source of spatial position markers basically comes from the group of relational concepts that is claimed by Svorou to be close in frequency (as a source domain) to body part terms (Svorou 1993, 83-5).

(5) UP: *wilä 'Oberfläche, ober-, das Obere' PFU, ?PU

(Rédei 1986-1988, 573)

DOWN: *ala 'Raum unter etw., Unter-, das Untere' PU

(ibid., 6)

FRONT: *e $\delta$ e 'das Vordere, Raum vorder etw., Vorder' PFU

(ibid., 71)

BACK: *taka 'Hinterraum, das Hintere' PU

(ibid., 506)

IN: *śićä śinćä 'Inneres' PU

(ibid., 480)

If we accept Svorou's and Heine's opinion with respect to the origin of relational part names, we can add another point to the semantic reconstruction of the above etymologies. The assumed basic meanings of the spatial morphemes reconstructed for Proto-Uralic may reflect a kind of grammaticalized stage already, and these words may have originally referred to body parts or elements of human environment, as the results of typological studies suggest. A detailed study of the etymons and of the semantic changes observed in the individual daughter languages may make it possible to draw more concrete conclusions with respect the proto-language meaning of the individual etymologies.

\section{Further issues}

Finally, let me try to answer the question of whether it is possible to unambiguously determine the range of body part terms that may be

\footnotetext{
${ }^{11}$ Several considerations support our choice of the above etymons from among those reconstructed with a spatial role in Rédei (1986-1988): on the one hand, in several languages of the family, the basic spatial terms are continuations of just these etymons, and on the other hand, these words constitute a rather homogeneous system with respect to their proto-meanings reconstructed on the basis of their role in the daughter languages (cf. also Ojutkangas 2001, 29).
} 
grammaticalized into spatial markers. This question may be formulated in a more general manner: will our increasingly detailed knowledge of grammaticalization processes eventually allow us to detect and determine the non-grammatical source of each and every grammatical category? Can the source-target relationship be seen as universal (cf. Heine et al. $1991,155)$ ?

In the case of the lexical group discussed in this paper, the issue of which parts of the human body may represent a base of comparison for spatial orientation mostly logically follows from the structure and natural position of the body. That is why we observe that in many languages the same body part terms participate in grammaticalization processes resulting in space marking linguistic elements. However, individual languages may exhibit departures from the general tendencies, and we have to contradict Heine's following statement (formulated as a question): "What induces people worldwide to decide that a body-part like face, rather than navel or kneecap, provides the favorite model for developing expressions for the spatial concept 'front'? And why not the body-part nose? Why, in fact, is the nose notoriously ignored as a source for spatial orientation?" (Heine 1997, 47).

The Uralic languages partly disprove the examples mentioned by Heine. In Finnish, the noun for 'nose' has adverbialized to mean 'opposite' (nenäkkäin < nenä, cf. section 3), and it is characteristic of Finnish in general that a considerable percentage of body part names also occur as spatial markers (Jaakola 1997; Suoniemi-Taipale 1996). In Mansi folk songs, the body part name meaning 'knee' can also fulfil a spatial function, cf. N am sānsèmnè jūw tūläln, am pāltèmnè tì ' tūläln! 'bring him home to my knee, bring him to me' [knee-PxSg1-lat.] (Munkácsi 18921921, IV.7). However, these examples raise another problem: it is not easy to define the concept of grammaticalized body part name unambiguously. Occasional uses of body part terms in referring to spatial positions abound in languages, cf. Hungarian itt lohol a sarkamban/nyakamban 'he is close on my heels/breathing down my neck'; olyan közel hajol, hogy szinte az ember szájában van 'he leans as close as almost into one's mouth'; a város szívében 'in the heart of town'; a hegy gyomrában 'in the belly of the mountain', etc. In these examples, local relations are involved (behind, before, in something), yet the body part names involved cannot be taken to be place adverbs or postpositions; their spatial uses are rather bound, idiomatic. A criterion of grammaticalization could therefore be the lack of lexical boundness, a feature that goes together with an 
increase of the productivity of the given linguistic item. Further criteria can be borrowed from the general literature on grammaticalization: the process is characterised by a weakening and abstraction of the semantic content of the lexeme concerned. In the case of Finno-Ugric languages, another criterion may be participation in the three-directional system (cf. Hungarian szemben - szembe - szemböl 'opposite [at/to/from] < szem 'eye', Finnish päällä - päälle - päältä 'above [at/to/from]' < pää 'head'). Reconsidering the Hungarian examples listed above, we find that the case suffix use of such body part terms used for spatial position marking is also rather bound; they sound a lot less natural with case suffixes referring to other directions: (?) Ne gyere a sarkamba! 'Don't come into my heels [too close to me]'; (?) Gyere ki a sarkamból! 'Come out of my heels [follow me less closely]'. Another criterion suggesting a higher degree of grammaticalization is where a body part term may express more abstract relations than local ones since more abstract roles (like temporal or causal relations) have to be preceded by more concrete (local) roles, cf. Hungarian a házzal szemben 'opposite the house' - ezzel az érvvel szemben 'against/as opposed to this argument', also Finnish pä̈stä 'after' < pää 'head', Estonian käsil 'during' < käsi 'hand', etc.

However, it is impossible to formulate a thumb rule to tell us which body part names can be seen as "grammaticalized already", and it is likewise impossible to predict exactly which body part names will be grammaticalized in any particular language.

\section{Appendix}

\begin{tabular}{|c|c|c|c|c|c|}
\hline Source & & Target & Target & & Source \\
\hline \multirow[t]{6}{*}{ back } & $>$ & (1) after & before & $<$ & (1) eye \\
\hline & & (2) behind & & & (2) first (temp) \\
\hline & & (3) cause & & & (3) front \\
\hline & & (4) earlier & behind & $<$ & (1) back \\
\hline & & (5) then & & & (2) buttocks \\
\hline & & (6) up (spatial) & & & (3) follow \\
\hline \multirow[t]{2}{*}{ belly } & $>$ & (1) in (spatial) & & & (4) footprint \\
\hline & & (2) in (temp.) & & & \\
\hline
\end{tabular}




\begin{tabular}{|c|c|c|}
\hline Source & & Target \\
\hline body & $>$ & $\begin{array}{l}\text { (1) intensive refl. } \\
\text { (2) middle } \\
\text { (3) reciprocal } \\
\text { (4) reflexive }\end{array}$ \\
\hline bottom & $>$ & down (spatial) \\
\hline bowels & $>$ & in (spatial) \\
\hline breast & $>$ & front \\
\hline buttocks & $>$ & $\begin{array}{l}\text { (1) behind } \\
\text { (2) down }\end{array}$ \\
\hline ear & $>$ & locative \\
\hline eye & $>$ & $\begin{array}{l}\text { (1) before } \\
\text { (2) front }\end{array}$ \\
\hline face & $>$ & $\begin{array}{l}\text { (1) front } \\
\text { (2) up }\end{array}$ \\
\hline flank & $>$ & side (spatial) \\
\hline foot & $>$ & down \\
\hline forehead & $>$ & front \\
\hline hand & $>$ & $\begin{array}{l}\text { (1) agent } \\
\text { (2) five } \\
\text { (3) locative } \\
\text { (4) possessive }\end{array}$ \\
\hline head & $>$ & $\begin{array}{l}\text { (1) front } \\
\text { (2) intensive-refl. } \\
\text { (3) middle } \\
\text { (4) reflexive } \\
\text { (5) up }\end{array}$ \\
\hline heart & $>$ & in (spatial) \\
\hline lip & $>$ & locative \\
\hline liver & $>$ & locative \\
\hline mouth & $>$ & front \\
\hline neck & $>$ & locative \\
\hline shoulder & $>$ & up \\
\hline
\end{tabular}

\begin{tabular}{|c|c|c|}
\hline Target & & ource \\
\hline down & $<$ & $\begin{array}{l}\text { (1) bottom } \\
\text { (2) buttocks } \\
\text { (3) descend } \\
\text { (4) earth } \\
\text { (5) fall } \\
\text { (6) foot }\end{array}$ \\
\hline front & $<$ & $\begin{array}{l}\text { (1) breast } \\
\text { (2) eye } \\
\text { (3) face } \\
\text { (4) forehead } \\
\text { (5) head } \\
\text { (6) mouth }\end{array}$ \\
\hline in (spatial) & $<$ & $\begin{array}{l}\text { (1) belly } \\
\text { (2) bowels } \\
\text { (3) center } \\
\text { (4) heart } \\
\text { (5) interior }\end{array}$ \\
\hline locative & $<$ & $\begin{array}{l}\text { (1) area } \\
\text { (2) ear } \\
\text { (3) edge } \\
\text { (4) hand } \\
\text { (5) home } \\
\text { (6) house } \\
\text { (7) lip } \\
\text { (8) liver } \\
\text { (9) locative copu } \\
\text { (10) neck } \\
\text { (11) place } \\
\text { (12) side }\end{array}$ \\
\hline middle & 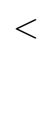 & $\begin{array}{l}\text { (1) body } \\
\text { (2) head } \\
\text { (3) reflexive }\end{array}$ \\
\hline side (spatial) & $<$ & flank \\
\hline up & $<$ & $\begin{array}{l}\text { (1) back } \\
\text { (2) face } \\
\text { (3) head } \\
\text { (4) shoulder } \\
\text { (5) sky }\end{array}$ \\
\hline
\end{tabular}

(Heine-Kuteva 2002) 


\section{References}

Benkő, Loránd 1967-1976. A magyar nyelv történeti-etimológiai szótára [A historicaletymological dictionary of the Hungarian language]. Akadémiai Kiadó, Budapest.

Heine, Bernd 1989. Adpositions in African languages. In: Linguistique Africain 2: $77-127$.

Heine, Bernd 1997. Cognitive foundations of grammar. Oxford University Press, Oxford.

Heine, Bernd 1999. Polysemy involving reflexive and reciprocal markers in African languages. In: Zygmunt Frayzyngier - Traci S. Curl (eds): Reciprocals: forms and functions, 1-29. John Benjamins, Amsterdam \& Philadelphia.

Heine, Bernd - Ulrike Claudi-Friederike Hünnemeyer 1991. From cognition to grammar. Evidence from African languages. In: Elizabeth Traugott-Bernd Heine (eds): Approaches to grammaticalization, 149-89. John Benjamins, Amsterdam \& Philadelphia.

Heine, Bernd - Tania Kuteva (eds) 2002. World lexicon of grammaticalization. Cambridge University Press, Cambridge.

Jaakola, Minna 1997. Genetiivin kanssa esiintyvien adpositioiden kieliopillistumisesta [On the grammaticalization of adpositions governing the genitive]. In: Tapani Lehtinen - Lea Laitinen (eds): Kieliopillistuminen. Tapaustutkimuksia suomesta [Grammaticalization. Case studies on Finnish]. Kieli 12, 121-56. Helsingin yliopiston suomen kielen laitos, Helsinki.

Jackendoff, Ray - Barbara Landau 1992. Spatial language and spatial cognition. In: Ray Jackendoff (ed.): Languages of the mind: Essays on mental representation, 99-125. MIT Press, Cambridge MA.

Munkácsi, Bernát 1892-1921. Vogul népköltési gyüjtemény I-IV [A collection of Mansi folk poetry 1-4]. Magyar Tudományos Akadémia, Budapest.

Munkácsi, Bernát - Béla Kálmán 1986. Wogulisches Wörterbuch. Akadémiai Kiadó, Budapest.

Ojutkangas, Krista 2001. Ruumiinosannimien kieliopillistuminen suomesssa ja virossa [The grammaticalization of body part terms in Finnish and Estonian]. SKS, Helsinki.

Rédei, Károly (ed.) 1986-1988. Uralisches Etymologisches Wörterbuch. Akadémiai Kiadó \& Otto Harrasowitz, Budapest \& Wiesbaden.

Rombandeeva, E. I. - Е. А. Kuzakova [Ромбандеева, Е. И. - Е. А. Кузакова] 1982. Словарь мансийско-русский и русско-мансийский. Просвещение, Ленинград.

Suoniemi-Taipale, Inga 1996. Ruumis - hahmottamisen lähtökohta. Ruumiinosannimeen perustuvat partikkelit [Body - the centre of perception. Particles based on body part names]. In: CIFU-VIII $5: 198-203$.

Svorou, Soteria 1993. The grammar of space (Typological Studies in Language 25). John Benjamins, Amsterdam \& Philadelphia. 
Address of the author: Katalin Sipőcz

Department of Finno-Ugristics

University of Szeged

Egyetem u. 2-6.

H-6722 Szeged

Hungary

sipocz@hung.u-szeged.hu

A preliminary version of this paper was presented at the 2003 session of the Budapest Uralic Workshop organised by the Department of Finno-Ugristics of the Research Institute for Linguistics of the Hungarian Academy of Sciences. 